\title{
A POLIFONIA E O PRINCÍPIO DO CONTRADITÓRIO: AS VOZES DO PROCESSO EM DIALOGIA
}

THE POLYPHONY AND THE PRINCIPLE OF

CONTRADICTORY: PROCESS VOICES IN DIALOGY

RESUMO: Esse artigo utiliza metodologia eminentemente bibliográfica e busca lançar luz sobre o princípio do contraditório em sua acepção substancial, ou seja, para além da simples participação no processo. Ante esse objetivo, importa entendermos como, por meio do princípio do contraditório, as partes no processo devem ser ouvidas e ter seus argumentos levados em consideração no ato decisório pelo julgador. Nesse diapasão, urge levar em consideração a colaboração que o dialogismo pode aportar para a melhor compreensão desse princípio. Assim, encontramos como resultado as contribuições que os estudos da linguística, especificamente o dialogismo de Bakhtin, possibilitam para que o processo seja visto como efetivo diálogo entre todos os partícipes do processo, incluindo então o magistrado e o parquet, afastando assim a escuta surda e a consequente reificação dos sujeitos do processo.

Palavras-chave: Princípio do contraditório. Dialogismo. Keywords: Contradictory principle. Dialogism. Bakhtin. Bakhtin.
ABSTRACT: This article uses eminently bibliographic methodology and seeks to shed light on the contradictory principle in a substantial sense, that is, beyond the simple participation in the process. Before this goal, it is important to understand how, through the contradictory principle, the parties to the case must be heard and have their arguments taken into consideration in the decision making act by the judge. In this vein, it is urgent to consider the collaboration that dialogism can contribute to a better understanding of this principle. Thus, we find as a result of the contributions to the study of linguistics, specifically dialogism Bakhtin, allow for the process to be seen as an effective dialogue among all participants in the process, then including the magistrate and the parquet, thus removing the deaf hear and the consequent reification of subjects of the process.

${ }^{1}$ Doutor em Direito pela Universidade Federal de Pernambuco (UFPE). Professor adjunto I da Faculdade de Economia, Administração, Atuária e Contabilidade da Universidade Federal do Ceará (UFC). Professor colaborador do Programa de Pós-Graduação em Sociologia da Universidade Estadual do Ceará (UECE). E-mail: dvdbarol@gmail.com. 


\section{INTRODUÇÃO}

Esse trabalho insere-se dentro das pesquisas sobre princípios jurídicos, do Direito Processual, e até mesmo do Direito Constitucional, bem como nos estudos sociolinguísticos. Realiza um estudo entre a linguística bakhtiniana e o direito, apresentando um diálogo pouco explorado entre essas duas áreas. Utiliza metodologia eminentemente bibliográfica e busca lançar luz sobre o princípio do contraditório em sua acepção substancial, observando que, para sua efetiva realização, as partes devem ter seus argumentos levados em consideração no ato decisório pelo julgador.

Nesse diapasão, urge levar em consideração a colaboração que o dialogismo pode aportar para a melhor compreensão desse princípio. Assim, apoiados em Bakhtin, buscamos compreender como o dialogismo possibilita que o processo seja visto como efetivo diálogo entre as vozes de todos os envolvidos no processo e não só entre as partes, afastando, desta maneira, a escuta surda do magistrado e consequentemente a reificação dos sujeitos da contenda.

Nosso escopo foi estabelecer um diálogo mais próximo entre o princípio do contraditório, o dialogismo e a polifonia bakhtiniana. O princípio do contraditório em sua acepção substancial não se satisfaz com a simples participação no processo pelos litigantes, haja vista que para sua efetiva realização as partes têm que, em decorrência do princípio da cooperação processual, ser ouvidas e terem seus argumentos levados em consideração pelo julgador. Nesse diapasão, o dialogismo e a polifonia possibilitam uma melhor compreensão do princípio do contraditório, pois a fala do agente processual deve ser compreendida como um enunciado desejo de resposta dos demais sujeitos do processo e inserida em meio a vozes que Ihe aportam o seu sentido específico.

Assim, apoiados em Bakhtin, buscamos compreender se a polifonia e o efetivo diálogo entre os sujeitos processuais favorecem a realização de um processo pautado pelo contraditório, levando-se em consideração todas as vozes que o constroem e não só a voz do juiz que enuncia dogmaticamente a decisão judicial. 


\section{PRINCÍPIO DO CONTRADITÓRIO SUBSTANCIAL}

Por devido processo legal entendemos o fato de se ter que obedecer às normas previamente estipuladas em lei, assegurando que o acesso e o desenvolvimento do processo obedeçam a normas previamente estabelecidas. O devido processo legal é verdadeiro princípio informativo que ligado ao processo e ao procedimento enfaixa em torno de si o contraditório e a ampla defesa. O artigo 5ㅇ da Constituição Federal faz menção a ambos os princípios afirmando que aos litigantes, em processo judicial ou administrativo, e aos acusados em geral são assegurados o contraditório e a ampla defesa.

O contraditório, além de constituir-se em manifestação do estado de direito, tem íntima ligação com a igualdade das partes e o direito de ação, assim tanto o direito de ação quanto o de defesa são manifestações do princípio do contraditório, segundo Nery Jr. (2004). Daí a garantia do contraditório ser inerente às partes litigantes, assim como ao assistente litisconsorcial e simples e ao parquet (mesmo como fiscal da lei). Todo aquele que possui alguma pretensão de direito material a ser deduzido tem o princípio a seu favor. O juiz, como sujeito processual, não tem o direito, mas o dever de assegurar o contraditório $^{2}$. Nesse mesmo sentido o processo é um instrumento de pacificação social, devendo ele se realizar sob o manto do contraditório. Desta maneira, o contraditório é inerente ao processo, sendo que a ampla defesa é uma consequência do contraditório e não se confundindo com este ${ }^{3}$.

O contraditório, além de constituir-se em manifestação do Estado de direito, tem íntima ligação com a igualdade das partes e o direito de ação, destarte tanto o direito de ação quanto o de defesa são manifestações do princípio do contraditório. A ampla defesa também se aplica a ambos os contendores, pois pode o autor ter sua pretensão resistida

\footnotetext{
${ }^{2} \mathrm{O}$ juiz, como sujeito processual, não tem o direito, mas o dever de assegurar o contraditório. Neste sentido, portanto, ele deve observar em questões de ofício também o contraditório. Os poderes do julgador são aumentados, impondo a este o dever de informar às partes as iniciativas que pretende realizar, "de modo a permitir um espaço de discussão em contraditório", conforme aponta Theodoro Jr e Nunes (THEODORO JR.; NUNES, 2009, p. 137).

${ }^{3}$ Além de tomar conhecimento de todos os termos do processo (contraditório) a parte também tem o direto de alegar a provar o que alega e de não se defender. Ampla defesa não se restringe à contestação, mas compreende também um conjunto de atos tendentes a proteger um direito, seja mediante a exposição das pretensões inerentes ao mesmo, seja mediante a atitude de repelir as pretensões do adversário; função do advogado no patrocínio de seus clientes; exceções dilatórias, peremptórias ou mistas, contra a demanda principal (PORTANOVA, 1999).
} 
por fato novo trazido aos autos pelo réu. Nesse caso, necessitaria o autor de ampla defesa para replicar em razão desses fatos novos que lhe afasta a pretensão ${ }^{4}$.

Ante tudo o que foi aludido até aqui, interessa-nos aprofundar o fato de em um Estado democrático de direito o contraditório dever ser efetivo e não apenas formal. Para tanto não deve haver barreiras e entraves injustificáveis ao trabalho da parte em prol de demonstrar seu direito, conforme asserta Portanova (1999), posto que todos os meios necessários têm de ser empregados para que não se manifeste posição privilegiada em detrimento de um dos litigantes. Nesse âmbito, afirma-se que o contraditório pode ser decomposto em duas garantias: a possibilidade de participação e a possibilidade de influência na decisão. Os contendores têm o direito de serem ouvidos e realizar as provas paritariamente no processo em todos os seus termos.

Desta forma, por contraditório deve entender-se tanto a necessidade de dar conhecimento à existência da ação, de todos os atos do processo às partes e a possibilidade de as partes reagirem aos atos que lhe sejam desfavoráveis, quanto de poder efetivamente influenciar no resultado final da demanda. Ou seja: ser comunicado, poder se manifestar e ter sua manifestação lavada em consideração na sentença. O primeiro aspecto, a participação no processo, é chamado de formal, ao passo que a segunda, é nomeada de substancial. O contraditório formal seria a simples intimação para manifestarse e produzir provas, já o efetivo, ou substancial, seria a possibilidade de as partes efetivamente criarem dúvidas no convencimento do juiz ou até influírem em seu convencimento.

Nesse sentido, o aspecto substancial abordará o poder de influência das partes ante o juiz. Entretanto, isso não implica dizer que haverá disparidade de armas entre os litigantes, pois, pelo contrário, somente quando as forças do processo, de busca e revelação da verdade, são efetivamente distribuídas com irrestrita igualdade é que se pode falar de processo com contraditório e ampla defesa. Falar, então, de contraditório substancial significa dizer que não adianta permitir, apenas, que a parte participe do

\footnotetext{
${ }^{4}$ Afastamo-nos assim, da corrente doutrinária de Marinoni que entende que o direito de ação compreende tanto ação quanto defesa.
} 
processo, que seja ouvida, tendo fundamentalmente que possuir condições de influenciar o conteúdo da decisão.

Deste modo, de acordo com Theodoro Jr e Nunes (2009), o contraditório constitui uma verdadeira garantia de não surpresa que impõe ao juiz o dever de provocar o debate acerca de todas as questões, inclusive as de conhecimento oficioso, impedindo que aplique normas ou embase decisões sobre fatos completamente estranhos à dialética defensiva de uma ou de ambas as partes. O princípio do contraditório deixa assim de ser a defesa, no sentido negativo de oposição ou resistência à atuação alheia, passando a ser a possibilidade de influir, agora no sentido positivo do termo, no desenvolvimento e no êxito do processo. É o direito de ver seus argumentos apreciados na fundamentação do magistrado.

Essa ideia decorre da influência do princípio da cooperação no processo, postando o juiz como ator ativo no contraditório, como agente colaborador do processo e não mais como boca de lei ou seu mero fiscal. O processo é o fruto da cooperação entre os atores jurídicos, de modo que todos possam colaborar para a prolação do ato final sobre o litígio. Para Dinamarco (1996), essa participação legitima o exercício de qualquer poder. A dialética do processo expressa-se na cooperação mais intensa entre o juiz e os contendores, seja para a descoberta da verdade dos fatos que não são do conhecimento do primeiro, seja para o bom entendimento da causa e dos seus fatos, seja para a correta compreensão das normas de direito e apropriado enquadramento dos fatos nas categorias jurídicas adequadas. Daí, ele afirmar que o contraditório, passa a abranger o direito das partes ao diálogo com o juiz, não bastando somente que tenham a faculdade de ampla participação, "é preciso que também este participe intensamente, respondendo adequadamente aos pedidos e requerimentos das partes, fundamentando decisões e evitando surpreendê-las com decisões de-ofício inesperadas" (DINAMARCO, 1996, p. 285). A cooperação assim informa e qualifica o contraditório.

Deste modo, seguindo o princípio da cooperação, o magistrado terá de observar os deveres de esclarecimento, de consulta e de prevenção. No esclarecimento, o magistrado poderá requerer esclarecimentos das partes quando estiver em dúvida sobre suas alegações. Na consulta, deve o juiz consultar as partes sobre questão não alvitrada no 
processo, ou seja, não pode decidir sobre questão de fato ou de direito, mesmo que possa atuar de ofício, sem que as partes sobre elas não sejam intimadas para manifestar-se. Por fim, na prevenção, deve o magistrado apontar as deficiências das postulações das partes de modo a serem superadas, valendo genericamente para toda situação em que o êxito da ação possa ser frustrado pelo uso inadequado do processo.

Resta evidente, portanto, que o princípio do contraditório, quando ladeado pela cooperação, deve, junto com seu status passivo ou formal, exigir o diálogo entre os sujeitos processuais. Esse diálogo alcança não apenas os polos opostos da lide, mas também o juiz e o Ministério Púbico (mesmo como custos legis). O contraditório fora de seu tradicional contexto que garante a paridade formal de armas entre os litigantes, demanda, além de a parte ser ouvida, que o magistrado leve em consideração o que foi dito em suas ações. O diálogo passa a ser, se não o centro, do contraditório, seu elemento principal, posto que se não forem levados em consideração seus argumentos, de nada adianta ele ter o direito de os trazer a juízo. É sobre esse diálogo que passaremos no próximo tópico a tecer alguns comentários.

\section{O DIALOGISMO BAKHTINIANO}

A colaboração das partes, como vimos, é o termo-chave do conceito de contraditório. Para Santos (2011), essa colaboração somente é possível com um efeito dialógico ou a possiblidade de efetiva participação de todos os participantes no processo. Em decorrência das modernas investidas teóricas sobre o princípio do contraditório, esse é visto como garantia de diálogo ou de participação democrática no processo. Por meio do diálogo, o contraditório pode ser definido como o fato de ninguém poder ser atingido por uma decisão judicial na esfera de interesses, sem ter a possibilidade de influir eficazmente na sua formação em igualdade de condições com a parte oposta.

O contraditório exercido em diálogo não se limita apenas às partes da demanda, expandindo-se também para o juiz, assumindo a partir desse parâmetro uma posição ativa. Conforme explica Santos (2011), o diálogo não se restringe às partes, envolvendo também o magistrado para que, de forma dialética, ao ouvir as teses de cada parte, possa refletir, 
discutir e formar sua síntese, expondo-a pública e fundamentadamente à sociedade democrática. Leonardo Greco (2010, p. 541), a esse respeito, afirma que

Exige-se um contraditório participativo, em que o juiz dialogue com as partes, e não apenas as escute. Ao expor as suas opiniões ou os possíveis reflexos das alegações e das provas que estão sendo objeto de cognição, o juiz confere as partes a oportunidade de acompanharem seu raciocínio e de influenciarem na formação do seu juízo.

Deste modo, só há diálogo se todas as partes concordam em escutar uma a outra e em expor seus fundamentos. Veda-se, por decorrência, a surpresa no processo. As partes, além de notificadas, devem participar de modo que nenhuma questão seja decidida sem a prévia audiência delas; ou ainda, de maneira ainda mais contundente: as partes têm que possuir a possibilidade de influir no convencimento do juízo. Essa demanda última do contraditório substancial é o mais básico pressuposto do enunciado dialógico de Bakhtin.

Em Bakhtin palavra e enunciado se diferem e isso implica uma distinção essencial para os estudos que procuraremos realizar. A palavra possui conclusibilidade de significado e de forma gramatical, mas essa é de caráter abstrato, pois é o acabamento do elemento e não do todo como é o enunciado. A palavra não possui autor, ela é de ninguém. Para Bakhtin as palavras, "em si mesmas nada valorizam, mas podem abastecer qualquer falante e os juízos de valor mais diversos e diametralmente opostos dos falantes" (2010, p. 290). As palavras são neutras e em si mesmas não têm aspecto expressivo. Elas o adquirem tão somente em um enunciado concreto. Bakhtin (2010, p. 290) asserta, para introduzir a relação que existe entre a palavra/oração e o enunciado, o exemplo de

uma oração como "Ele morreu" pelo visto incorpora uma determinada expressão, e a incorpora ainda mais uma expressão como "Que alegria!" (...) Enquanto orações elas são desprovidas dessas expressão, são neutras. Dependendo do contexto do enunciado, a oração "Ele morreu" pode traduzir também uma expressão positiva, de alegria e até de júbilo. E a oração "Que alegria!", no contexto de um determinado enunciado, pode assumir tom irônico ou amargamente sarcástico".

A palavra, assim como a oração, é a unidade básica da língua. Tomada isoladamente é desprovida da capacidade de determinar imediatamente tudo o que se quis dizer, pois não conseguimos perceber o diálogo no qual ela se insere, não alcançamos as orações que a antecedem e a sucedem do mesmo ou de outro falante. Só quando as palavras e as 
orações estão inseridas em um contexto dialógico podemos tê-las como enunciados. Quando as palavras estão emolduradas pela alternância de sujeitos do discurso e refletem a realidade extraverbal, elas requerem uma resposta, tornam-se responsivas. A palavra é a afirmação do real apenas no contexto de um determinado enunciado.

Daí, os dicionários trazerem inúmeros significados para as palavras pesquisadas. Mas, a partir do momento em que concretamente contextualizamos a palavra afastamos vários sentidos irrelevantes, absurdos, paradoxais, impossíveis como também explica Wittgenstein 5 . Bakhtin (2010, p. 288) traz como exemplo a oração “o Sol saiu. É hora de me levantar". Esta oração, para ser totalmente compreendida, necessita aparecer dentro de um diálogo que lhe dê concretude. A compreensão responsiva (ou a resposta em voz alta) ante essa oração é "sim, realmente está na hora" (BAKHTIN, 2010, p. 288). As palavras não são de ninguém, mas ao mesmo tempo "nós a ouvimos apenas em determinadas enunciações individuais, e aí as palavras já não têm expressão apenas típica porém expressão individual externada com maior ou menor nitidez (em função do gênero), determinada pelo contexto individual do enunciado" (BAKHTIN, 2010, p. 293). A partir do momento em que a oração se insere em uma corrente de outras orações que lhe antecedem e a sucedem, agregando determinado sentido ao mesmo tempo em que rejeita inúmeros outros, ela passa então a ser enunciado.

Os limites do enunciado são determinados pela alternância dos sujeitos do discurso. O enunciado é limitado pela alternância dos sujeitos do discurso e reflete imediatamente a realidade extraverbal. A palavra tem seu sentido determinado pelo contexto de um enunciado determinado. Afirma Bakhtin (2010, p. 289) que "só funcionando como um enunciado pleno ela se torna expressão da posição do falante individual em uma situação concreta de comunicação discursiva". Importa aqui percebermos que o enunciado é um elo na cadeia da comunicação discursiva, indicando a posição do falante no campo do objeto e do sentido.

Toda compreensão da fala viva, do enunciado vivo, conforme Bakhtin, "é de natureza ativamente responsiva (embora o grau desse ativismo seja bastante diverso);

\footnotetext{
${ }^{5}$ Sobre jogos de linguagem e sentido construído a partir do uso ver Wittgenstein.
} 
toda compreensão é prenhe de resposta, e nessa ou naquela forma a gera obrigatoriamente: o ouvinte se torna falante" (BAKTIN, 2010, p. 271). A compreensão passiva do significado do discurso ouvido é apenas o momento abstrato da compreensão ativamente responsiva real e plena que se atualiza mediante a resposta em voz alta. $\mathrm{Na}$ teoria bakhtiniana, o próprio falante não espera uma compreensão passiva, daí percebermos que o ouvinte com sua compreensão passiva, que é representado pelos esquemas tradicionais da linguística, não corresponde ao participante real da comunicação discursiva. Isso acontece porque o discurso só pode existir de fato na forma de enunciações concretas de determinados falantes, sujeitos do discurso.

Cada enunciado possui um determinado conteúdo semântico-objetal, sendo impossível um enunciado absolutamente neutro. A oração adquire o aspecto expressivo em um enunciado concreto, posto que tanto palavra quanto oração são desprovidos de entonação expressiva. Portanto, a emoção, o juízo de valor e a expressão são estranhos à palavra da língua e surgem unicamente no processo do seu emprego vivo em um enunciado concreto, pois, em si mesmo, o significado de uma palavra é extra-emocional, sem referência a realidade concreta.

O enunciado não é só, não existe enunciado adâmico. Ele existe na cadeia discursiva. A estrutura da enunciação é, portanto, de natureza social, pois "a elaboração estilística da enunciação é de natureza sociológica e a própria cadeia verbal, à qual se reduz em última análise a realidade da língua, é social. Cada elo da cadeia é social, assim como toda a dinâmica da sua evolução" (BAKHTIN, 1997, p. 122). No caso, há uma posição ativa do falante e do ouvinte dentro do fluxo comunicativo. Essas posições, no processo comunicativo real, são fiç̧ões, pois o ouvinte, ao perceber e compreender o significado do discurso emitido pelo falante, ocupa, além da função passiva, uma atitude ativa, denominada responsiva, pois, para Silva (2010), o processo de compreensão do enunciado é 'prenhe de resposta'. Cada enunciado acaba sendo um elo na cadeia complexa de outros enunciados $^{6}$. Assim, Bakhtin (2010, p. 275) esclarece isso afirmando que

\footnotetext{
${ }^{6}$ Augusto Ponzio a esse respeito asserta que "a enunciação é sempre de alguém para alguém. Responde e reclama uma resposta. Esta resposta ultrapassa os limites do verbal" (PONZIO, 2008, p. 95).
} 
[...] os limites de cada enunciado concreto como unidade da comunicação discursiva são definidos pela alternância dos sujeitos do discurso, ou seja, pela alternância dos falantes. Todo enunciado [...] tem, por assim dizer, um princípio absoluto e um fim absoluto: antes do seu início, os enunciados de outros; depois do seu término, os enunciados responsivos de outros.

A forma linguística apresenta-se aos locutores no contexto de enunciações precisas, implicando sempre um contexto ideológico preciso. Bakhtin (1997, p. 95) deixa claro que "não são as palavras o que pronunciamos ou escutamos, mas verdades ou mentiras, coisas boas ou más importantes ou triviais agradáveis ou desagradáveis etc. A palavra está sempre carregada de um conteúdo ou de um sentido ideológico ou vivencial". Só reagimos às palavras que despertam ressonâncias vivenciais ou ideológicas. Contudo, toda enunciação humana é organizada, do ponto de vista de seu conteúdo, de sua significação, fora do indivíduo pelas condições extra-orgânicas do meio social. Deste modo, para Bakhtin (1997, p. 121), "a enunciação enquanto tal é um puro produto da interação social, quer se trate de um ato de fala determinado pela situação imediata ou pelo contexto mais amplo que constitui o conjunto das condições de vida de uma determinada comunidade linguística". Assim, o centro organizador de toda enunciação individual (parole) não é interior, mas exterior, situando-se no meio social que envolve o indivíduo.

No discurso, todos os nossos enunciados são plenos de palavras dos outros, de um grau vário de alteridade ou de assimilabilidade. O enunciado é cheio de tonalidades dialógicas. A nossa própria ideia - seja filosófica, científica ou artística - nasce e se constrói no processo de interação e luta com os pensamentos dos outros, por conseguinte, todo enunciado é permeado pelo enunciado do outro, pela voz de outro sujeito. Um enunciado, portanto, reflete o processo do discurso, os enunciados dos outros, os elos antecedentes da cadeia discursiva. Essas palavras advindas dos outros não são neutras, trazendo consigo a sua expressão, seus valores que assimilamos ou reelaboramos.

Desta forma, as palavras, como afirma Bakhtin, são universais, absolutas e, por isso, possui de serem significadas no caso concreto, necessitando para isso de outros elementos, outras, palavras, outros enunciados, contextos sociais, poder etc. Como o sentido é partilhado entre a comunidade linguística, o sentido não é dado por uma pessoa ou um órgão, o sentido está alhures, nos outros discursos. Compreender, nesse caminho, é 
orientar-se em direção ao dito e fazer corresponder cada palavra dessa enunciação junto a uma série de palavras suas, formando réplicas. Por isso, para Bakhtin (1997, p. 132, “a compreensão é uma forma de diálogo (...). Compreender é opor à palavra do locutor uma contrapalavra").

A adoção desse viés, portanto, leva o magistrado a romper com a crença em formulações definitivas, acabadas e com o discurso monológico, que procura dizer a última palavra sobre os sujeitos que a eles se submetem. A adoção dessa postura nas relações sociais rompe com as visões unilaterais dos institutos e, no Direito, afasta a utilização da natureza jurídica das coisas como uma verdade última. A análise dos "dados" não se restringe à sua manifestação "objetiva", pois, nesse dado que emergiu, estão elementos do contexto e da história, cabendo-Ihe, então, a tarefa de buscar, segundo Amorim e Rossetti-Ferreira (2008), os múltiplos significados que o envolvem e que com ele estão em harmonia e embate, articulando-se, repetindo e se transformando.

A pesquisa ou o processo judicial, desde uma perspectiva dialógica, é compreendida como um encontro entre sujeitos e mais, sujeitos com discursos distintos e que produzirão significados múltiplos e conflitantes, conforme aduz Bessa (2010). O grande compromisso do juiz, longe de ser o de homogeneizar ou apresentar um discurso monofônico, uma natureza jurídica, é assumir o caráter conflitivo e paradoxal, renunciando à ilusão de transparência, tanto do discurso do outro como do seu próprio.

$\mathrm{O}$ ato de renunciar a essa transparência, no entanto, não pode ser confundido com a renúncia de objetivação e conceitualização. O juiz tenta captar algo do modo como o sujeito se vê e depois se posiciona plenamente no seu lugar exterior, a fim de contemplar o horizonte do jurisdicionado, completando-o com sua visão excedente e externa, realizando o que Bakhtin chama de exotopismo. O olhar do juiz não coincide com o olhar que a pessoa tem de si mesma, pois ele a enxerga de outra posição e com outros valores; assim, dá-Ihe outros sentidos.

\section{O PRINCÍPIO DIALÓGICO E O CONTRADITÓRIO}

O enunciado, como referido anteriormente, não é só, não existe enunciado adâmico. Ele existe dentro da cadeia discursiva, havendo uma posição ativa do falante e do 
ouvinte dentro do fluxo comunicativo. Assim, no processo comunicativo real, o ouvinte, ao perceber e compreender o significado do discurso emitido pelo falante ocupa, além da função passiva, uma atitude ativa, denominada responsiva, pois a fala traz consigo o pedido de resposta, de diálogo. Cada enunciado, portanto, implica uma cadeia complexa de outros enunciados.

Pressupõe-se, destarte, que o enunciado está há muito tempo escondido em outros enunciados. Cada enunciado ${ }^{7}$ advém de outros enunciados, daí a enunciação estar repleta de tonalidades dialógicas. A nossa própria ideia - seja filosófica, científica ou artística nasce e se perfaz na interação e luta com os pensamentos dos outros, de sorte que todo enunciado é permeado pelo enunciado do outro, pela voz de outro sujeito. O sentido, em razão do dialogismo, é partilhado pela comunidade linguística, não sendo concedido por uma pessoa ou um órgão, pois o sentido está alhures, nos outros enunciados. É como se houvesse, para Bakhtin, um texto subentendido. A ideia recai sobre a ideação de outrem, ou seja, "são pensamentos sobre pensamentos, vivências das vivências, palavras sobre palavras, texto sobre textos" (BAKHTIN, 2010, p. 307), ou, como claramente explica Deleuze e Guatarri (1995, p. 13-14),

[...] se a linguagem parece sempre supor a linguagem, se não se pode fixar um ponto de partida não linguístico, é porque a linguagem não é estabelecida entre algo visto (ou sentido) e algo dito, mas vai sempre de um dizer a um dizer. Não acreditamos, a esse respeito, que a narrativa consista em comunicar o que se viu, mas em transmitir o que se ouviu, o que o outro disse. Ouvir dizer. Nem mesmo basta evocar uma visão deformante vinda da paixão. A "primeira" linguagem, ou, antes, a primeira determinação que preenche a linguagem, não é o tropo ou a metáfora, é o discurso indireto. (...) isto porque todo discurso é indireto, e a translação própria à linguagem é a do discurso indireto ${ }^{8}$.

\footnotetext{
${ }^{7}$ Bakhtin utiliza o termo enunciado para determinar o sentido de uma palavra abstrata em um contexto específico. Como Fairclough não adota esse vocábulo, o aplicamos apenas quando os autores expressamente o utilizarem, posto que optamos, de acordo com a ADC, pelo uso de texto, gênero, discurso e prática social.

${ }^{8}$ Essa ideia de Deleuze vai implicar que "não existe comunicação individual nem mesmo sujeito de enunciação. (...) a enunciação remete, por si mesma, aos agenciamentos coletivos. Assim, compreende-se que só há individuação do enunciado, quando o agenciamento coletivo impessoal o exige e o determina. Esse é precisamente o valor exemplar do discurso indireto, e sobretudo do discurso indireto 'livre': não há contornos distintivos nítidos, não há antes de tudo, inserção dos enunciados diferentemente individuados, nem encaixe de sujeitos de enunciação diversos, mas um agenciamento coletivo que irá determinar como sua consequência os processos relativos de subjetivação, as atribuições de individualidade e suas distribuições moventes no discurso. Não é a explicação dos sujeitos que explica o discurso indireto; é o agenciamento, tal como surge livremente nesses discursos, que explica todas as vozes presentes em uma voz, as risadas de menina em um monólogo de Charlus, as línguas em uma língua, as palavras de ordem em uma palavra" (DELEUZE; GUATARRI, 1995, p. 18-19). Deste modo, o agente se utiliza dos sentidos, palavras, vozes que estão aí, pensando ser de sua autoria, mas este não passa de um transmissor das palavras, ideias e vozes de outrem. A palavra sempre é redundante.
} 
Assim, se uma palavra possui sentido, é porque ela resulta de uma vivência dialógica, uma vez que, para Bakhtin, “o falante não é um Adão bíblico” (2010, p. 300), não se relaciona apenas com objetos virgens, nomeando-os pela primeira vez. O objeto, por assim dizer, já está ressalvado, contestado, elucidado e avaliado de modos distintos. No enunciado, portanto, há o cruzamento, a convergência e a divergência de vários pontos de vista, de visões diversas de mundo no decurso da situação dialógica. Desta maneira, com o dialogismo, insere-se o magistrado na contingência dos argumentos, na limitação dos fatos, no imperfeito da vida. Afasta-se o viés autoritário, persuasivo, inserindo-se e acatando-se o processado e o argumentado na lide.

O processo é diálogo prenhe de perguntas e desejo de respostas, não dar ouvidos às perguntas é decidir sem alteridade, sem a percepção de que é com o outro que damos sentido à vida e ao processo. A decisão criadora de norma é plena de palavras dos outros, de um grau variado de alteridade ou de assimilabilidade, pois todo texto, sem exceção, é dialógico. Na intelecção de Ferraz, no discurso dialógico, os dois polos do diálogo estão obrigados a levar-se mutuamente em conta, ao passo que a posição do ouvinte, no monológico, para Ferraz Jr. (1997, p. 24), "pode ser considerada como abstrata, isto é, a sua subjetividade desaparece enquanto individualidade, a sua adesão ao discurso aparece suspensa, não existe expectativa de reação ativa". Neste sentido, o Direito, a despeito do Poder que lhe conduza, pode ser monológico na expressão, mas sempre é dialógico em sua constituição, pois, conforme explica Araújo (2011, p. 74), “a própria estrutura do discurso monológico insere-se em uma dinâmica dialógica, na medida em que sucede ou responde a outro discurso anterior, ainda que esta sucessão não fique explicita no texto". Toda palavra, história, discurso é uma elaboração dialógica, diversa, aberta e plural.

Toda investigação jurídica está sempre às voltas com perguntas e respostas, ou se está questionando os pontos de partida em uma atitude zetética (dialógica) ou os está pressupondo em uma postura dogmática (monológica). No discurso jurídico, a adoção de uma postura monológica repercute, como pensamento tecnológico, em dogmatizar seus pontos de partida e problematizar a sua aplicabilidade na solução de conflitos, como explica Ferraz (2010). Ao contrário, o discurso dialógico põe à prova a sustentabilidade de 
uma ação linguística que se pretende dotada de autoridade, problematizando o objeto da discussão como um dubium em oposição a um certum dogmático, ainda conforme aduz Ferraz (1997). Araújo (2011), com a mesma preocupação, ressalta que o discurso normativo, por exemplo, possui aspecto racional monológico, porquanto nem todas as asserções são questionáveis ou criticáveis, pois, dentro da dogmática jurídica, não é permitido ao ouvinte participar ativamente, sendo sua única reação o reconhecimento de que sua conduta atenderá à direção da prescrição normativa. Daí, Ferraz (1997, p. 116) chamar a atenção para o fato de que a lei "impõe e exige obediência: não se pode aceitar parcialmente uma lei, desejar cumpri-la apenas em parte". O aspecto monológico da linguagem normativa, portanto, está em sua função prescritiva enquanto forma de regramento de condutas.

Esse aspecto monológico da linguagem jurídica refere-se tanto aos textos de lei quanto às normas jurídicas estabelecidas em um âmbito normativo. As decisões finais de processos que, depois da realização da jurisdição, não comportam mais recontextualizações também são monológicas. Até essa decisão final, contudo, a norma jurídica está inserida no movimento dialógico constituidor do Direito. Como em regra o Direito se realiza por meio de processos e procedimentos, sua estrutura constitutiva é necessariamente dialógica. Assim, o Direito constitui-se dialogicamente e o contraditório é o cerne do dialogismo, tal qual raciocina Ferraz (1997).

Tanto os textos legais quanto as decisões processuais possuem um momento específico monológico, contudo, tais ocasiões específicas são precedidas ou sucedidas por um sistema dialógico que produz, por meio do contraditório, os sentidos jurídicos. Deste modo, pode-se inferir que não só o processo em si, por meio do contraditório, é dialógico, mas o próprio Direito, quando se flexiona sobre os porquês das decisões, é dialógico. Assim, o dialogismo tanto sustenta o modo de produção da decisão dogmática, quanto aciona o movimento questionador destas próprias decisões.

\section{CONCLUSÃO: A POLIFONIA E O DIREITO}

O princípio dialógico que determina o sentido dos enunciados é, indubitavelmente, o elemento fundante do mundo jurídico. O dialogismo, como princípio constitutivo da 
linguagem, é a condição do sentido do Direito tanto na construção da razão dogmática quanto na busca zetética. A colaboração das partes, termo-chave do contraditório, possibilita a efetiva participação de todos os participantes no processo, incluindo o magistrado. Com o contraditório material, que impõe o diálogo entre todos os agentes do processo, afasta-se a escuta surda do julgador, as práticas, de acordo com Baptista (1999), que ouvem sem escutar. Na perspectiva de Ayres (2011, p. 150), "uma escuta surda se constitui quando no lugar de indagar as evidências que nos constituem como sujeitos, nos deixamos conduzir por estas reificando-as". Assim, sustenta Theodoro Jr. (2009, p. 107), que

[...] a decisão não pode mais ser vista como expressão apenas da vontade do decisor e sua fundamentação ser vislumbrada tão-só como mecanismo formal de legitimação de um entendimento que este possuía antes mesmo da decisão endoprocessual, mas deve buscar legitimidade, sobretudo, na tomada de consideração dos aspectos relevantes e racionais suscitados por todos os participantes, informando razões (na fundamentação) que sejam convincentes para todos os interessados no espaço público, e aplicar a normatividade existente sem inovações solitárias e voluntaristas.

Essa escuta afasta-se do dialogismo, pois não contradita com a parte, ouvindo suas demandas e respondendo suas dúvidas, mostrando-se distante e alheia às falhas de seus prejulgamentos, vinculando-se ao discurso monológico. O dialogismo insere o magistrado na contingência dos argumentos, na limitação dos fatos, na pluralidade de sentidos, no imperfeito da vida. Afasta o viés autoritário da decisão, submetendo-o ao argumentado pelas partes. O processo é um diálogo prenhe de perguntas e desejoso de respostas; não dar ouvidos às perguntas é decidir sem alteridade, sem a percepção de que é com o outro que damos sentido à vida e ao processo.

Destarte, o dialogismo de Bakhtin corrobora com a ideia de um processo cooperativo e com um contraditório substancial, pois impõe o diálogo não só entre as partes, mas evidentemente também com o juiz, que deve escutar as demandas das partes por meio de um contraditório efetivo, realizar a jurisdição de modo a alcançar eficientemente uma decisão satisfatória. Com base no enunciado responsivo o contraditório entre as partes refere-se e envolve necessariamente o juiz que está 
coordenando o processo e deve ser sensível a todos os argumentos das partes, devendo escutar todas as alegações e sobre elas se manifestar fundamentadamente.

Pelo dialogismo resta evidenciada que os enunciados responsivos proferidos pelas partes ao se manifestar dentro do processo são levados em consideração pelo juiz pelos argumentos e teses postos ante o magistrado. Cada enunciado implica uma cadeia complexa de outros enunciados e o processo jurídico enlaça vários atos processuais responsivos que necessitam do contraditório (diálogo) para avançar. A voz das partes, do juiz e do parquet se encontram e disputam sentido dentro do processo, não havendo, portanto, uma voz única, ou última, que diz a "Justiça" ou o "Direito" no caso concreto, pois nessa estão todas as outras.

Germano e Bessa (2010, p. 1.005), nesse sentido, explicam que, "mesmo que alguns textos tendam à monofonia e ocultem os diálogos sob a aparência de um discurso único, são constituídos pelo princípio dialógico e, portanto, não são atributos de um só autor". A polifonia se define pela convivência e pela interação, em um mesmo espaço, de uma multiplicidade de vozes e consciências independentes e imiscíveis. Essas vozes são sujeitos de seus próprios discursos. O dialogismo é, pois, o princípio constitutivo da linguagem e a condição do sentido do discurso. E diz-se que há polifonia quando esse dialogismo é notório, quando as vozes que o compõem são percebidas e evidenciam-se os confrontos e as tensões nessa constituição. Polifonia, então, é, segundo Barros (1997), como um cenário de contradições e oposições, onde vozes, ora discordantes ora dissonantes, emergem em permanente jogo e negociação.

Assim, toda palavra, toda história, todo discurso, toda decisão é polifônica, ou seja, não possui um significado estático e imutável, ao contrário, é uma construção dialógica, diversa, aberta e plural. O Direito, a despeito do Poder que Ihe conduza, nunca pode ser totalmente separado de suas raízes que se encontram na Cultura, daí que ele poderá ser monológico na expressão, mas é dialógico em sua constituição. À medida que afirmamos que a decisão judicial, assim como todo o Direito, é a resultante de inúmeros processos culturais, destituímos o Direito de seu altar e o inserimos na vida real ${ }^{9}$.

\footnotetext{
${ }^{9}$ O Direito é dependente dos processos culturais de troca, de inovação e de tradição. Nenhuma teoria é totalmente nova, nenhum princípio é absolutamente novo. O Direito se reproduz, adaptando-se às novas demandas sociais.
} 
Falar de polifonia é falar de vozes com diferentes pontos de vistas, que discordam e se chocam, gerando um acontecimento. Polifonia implica possibilidade de múltiplas vozes em um enunciado, sem necessariamente estarem em consonância ou síntese dialética. Portanto, a polifonia deixa ver o dialogismo entre essas múltiplas vozes, a palavra viva nas práticas discursivas, os incontáveis contextos em que o enunciado já foi anteriormente utilizado, como também, as vozes futuras que são condições de possibilidade da enunciação segundo Miranda (2008).

Tanto a polifonia quanto a monofonia integram o conceito de dialogismo, haja vista que são outras vozes distintas do enunciador. É por isso que Araújo (2011, p. 66) afirma que "os ordenamentos jurídicos são textos prescritivos que apresentam um caráter polifônico. A polifonia normativa encontra-se, por excelência, no texto da Constituição de cada Estado". Por exemplo, antes de 1988, durante os vinte e um anos de ditadura militar, o discurso oficial tentou sublimar a pluralidade da sociedade brasileira, dando a pensar que não havia dialogia e polifonia em seus textos. Os atos institucionais e todas as outras disposições normativas do período impunham um sistema jurídico aparentemente monofônico. O Ato Institucional no 1, por exemplo, dispunha, em seu preâmbulo, que as bases do "poder revolucionário" assentavam sua legitimidade não no povo, no pluralismo, pois "a revolução vitoriosa, como poder constituinte, se legitima por si mesma".

A monofonia pressupõe a reificação do outro, uma aceitação passional do enunciado, um calar-se ante o mundo. O dialogismo da Constituição cidadã transformou os objetos do governo militar, em sujeitos falantes, diversos e plurais aos moldes da sociedade brasileira. O dialogismo, de acordo com Bezerra (2008, p. 194), com sua isenta polifonia, procura "conhecer o homem em sua verdadeira essência como um outro 'eu' único, infinito, inacabável; não se propõe conhecer a si mesmo, conhecer seu próprio eu, propõe-se conhecer o outro, o 'eu' estranho". Daí, podemos assertar que polifônico é o texto em que se vislumbra a diversidade de vozes, como se observa no Direito dentro do processo ante a alteridade das partes em razão do contraditório. 


\section{REFERÊNCIAS}

AMORIM, K. S.; ROSSETTI-FERREIRA, M. C. Dialogismo e a investigação de processos desenvolvimentais humanos, Paidéia, v. 18, n. 40, p. 235-250, 2008, p. 244. Disponível em: <http://www.scielo.br/scielo.php?script=sci_serial\&pid=0103-863X\&lng=en\&nrm=iso>. Acesso em: 20 jan. 2015.

ARAÚJO, Clarice von Oertzen de. Incidência jurídica: Teoria e crítica. São Paulo: Noesis, 2011.

AYRES, Lygia Santa Maria. Direitos humanos e suas conexões com as diversas áreas da psicologia. GONDIM, Sonia Maria Guedes e CHAVES, Antônio Marcos (Org). Práticas e saberes psicológicos e suas conexões. Salvador: UFBA, 2011

BAKHTIN, Mikhail. Estética da criação verbal. São Paulo: WMF Martins Fontes, 2010.

BAKHTIN, Mikhail. Marxismo e filosofia da linguagem. 8. ed. São Paulo: Hucitec, 1997.

BAPTISTA, Luiz Antônio. A cidade dos sábios. São Paulo: Summus, 1999.

BARROS, Diana Luz Pessoa de. Contribuições de Bakhtin às Teorias do Discurso. In: BRAIT, B. (Org.) Bakhtin, dialogismo e construção do sentido. Campinas: Editora da UNICAMP, 1997.

BESSA, Letícia Leite. Adolescente, risco e proteção: um estudo narrativista dialógico sobre trajetórias de vida. 2010. 132 f. Dissertação - (Mestrado em Psicologia) - Faculdade de Psicologia, Universidade Federal do Ceará, Fortaleza, 2010.

BEZERRA, Paulo. Polifonia. BRAIT, Beth (Org.). Bakhtin: conceitos chaves. 4. ed. São Paulo: Contexto, 2008.

DELEUZE, Gilles; GUATARRI, Félix. Mil platôs: capitalismo e esquizofrenia. São Paulo: Ed. 34, 1995.

DINAMARCO, Cândido Rangel. A instrumentalidade do processo. 5ạ ed. São Paulo: Malheiros, 1996.

FERRAZ JR., Tercio Sampaio. A ciência do Direito. 2. ed. São Paulo: Atlas, 2010.

FERRAZ JR., Tercio Sampaio. Direito, retórica e comunicação. 2. ed. São Paulo: Saraiva, 1997.

FERRAZ JR., Tercio Sampaio. Função da dogmática jurídica. São Paulo: Revista dos Tribunais, 1980.

GERMANO, Idilva; BESSA, Letícia Leite. Pesquisas narrativo-dialógicas no contexto do conflito com a lei: considerações sobre uma entrevista com jovem autora de infração. Revista mal-estar e subjetividade. Fortaleza: Universidade de Fortaleza, v. X, n. 3, p. 9951.033, 2010.

GRECO, Leonardo. Instituições de processo civil: introdução ao direito processual civil. 2 ed. Rio de Janeiro: Forense, 2010. 
NERY JUNIOR, Nelson. Princípios do processo civil na Constituição Federal. São Paulo: editora Revista dos tribunais, 2004.

OST, François. O tempo do direito. Bauru: Edusc, 2005.

PONZIO, Augusto. A revolução bakhtiniana. São Paulo: Contexto, 2008.

PORTANOVA, Rui. Princípios do processo civil. Porto Alegre: Livraria do advogado, 1999.

SANTOS, Guilherme Luis Quaresma Batista. Algumas notas sobre o contraditório no processo civil. Revista de Processo. São Paulo: Revista dos tribunais. v. 36, n. 194, p. 69-97, abr. 2011.

SILVA, Beclaute Oliveira. O enunciado (dialógico) na decisão jurídica: Nas sendas de Mikhail Bakhtin. Revista de Informação Legislativa. Brasília, ano 47, n. 185, p.123-133, jan./mar. 2010.

THEODORO JR. Humberto.; NUNES, Dierle José Coelho. Uma dimensão que urge reconhecer ao contraditório no direito brasileiro: sua aplicação como garantia de influência, de não surpresa e de aproveitamento da atividade processual. Revista de Processo. São Paulo: Revista Dos Tribunais. no 168, p.107-141, fev. 2009.

OLIVEIRA, David Barbosa de. A polifonia e o princípio do contraditório: as vozes do processo em dialogia. RBSD Revista Brasileira de Sociologia do Direito, v. 4, n. 1, p. 321, jan./abr. 2017. 